\title{
PENERAPAN METODE PROBLEM SOLVING UNTUK MENINGKATKAN KEMAMPUAN PEMECAHAN MASALAH SISWA DALAM PEMBELAJARAN IPS DI SEKOLAH DASAR
}

\author{
Kanda Ruskandi \\ Hendra \\ UPI Kampus Purwakarta
}

\begin{abstract}
ABSTRAK
Penelitian ini dilatarbelakangi oleh hasil observasi sebelumnya bahwa pelaksanaan pembelajaran IPS di kelas V SDN Ciseureuh Kecamatan Purwakarta kurang bervariasi sehingga siswa kurang termotivasi untuk berperan aktif dalam kegiatan pembelajaran. Hal tersebut perlu diperbaiki dengan cara merubah pendekatan pembelajaran dari yang bersifat konvensional kepada pendekatan pembelajaran yang bersifat inovatif. Salah satunya adalah penerapan model pembelajaran yang dapat meningkatkan kemampuan siswa dalam pemecahan masalah yaitu metode problem solving. Penelitian secara umum bertujuan untuk mengetahui : 1). Kemampuanpemecahan masalah siswa kelas V SDN Ciseureuh dengan menerapan metode Problem Solving; 2) Hasilbelajar siswa kelas 5 SDN Ciseureuh dalam pembelajaran IPS selama penerapan metode problem solving. Jenis Penelitian yang digunakan adalah Penelitian Tindakan Kelas (PTK), karena penelitian ini bertujuan untuk memperbaiki pembelajaran di kelas. Subjek penelitian adalah guru dan siswa kelas $\mathrm{V}$ berjumlah 37 orang. Instrumen penelitiannya adalah lembar observasi dan tes hasil belajar. Penelitian ini dilihat dari aspek proses, telah berhasil mengubah pola pikirdan cara siswa dalam kegiatan pembelajaran yang sebelumnya lebih menekankan kepada penguasaan bahan melalui informasi dan bersifat pasif menjadi sistem belajar yang bersifat aktif dan mampu memecahkan masalah, sedangkan dilihat dari aspek konten penelitian ini, juga telah dapat meninghatkan hasil belajarnya.
\end{abstract}

Kata Kunci: Metode Problem Solving, Pemecahan Masalah, Pembelajaran IPS

\section{A. Pendahuluan}

IImu pengetahuan sosial (IPS) merupakan bidang studi yang diadopsi dari dunia barat dengan istilah Social Studies.IPS lebih kepada hal yang bersifat praktis, yaitu memberikan pengalaman kepada siswa untuk dapat hidup di masyarakat, dan mampu memecahkan permasalahan sosial. Sapriya (2007:4) menyatakan bahwalPS di sekolah penekanannya pada aspek pengembangan berpikir peserta didik sebagai bagian dari masyarakat untuk berperan serta dalam memecahkan masalah. Untuk itu dapat dimaknai bahwa kajian IPS di sekolah adalah sebagai program pendidikan selalu terkait dengan masalah pendekatan, metodologi, penilaian di dalam kerangka proses pendidikan di sekolah.

Beberapa hal yang masih akrab terjadi di sekolah dasar dalam pembelajaran IPS,yaitu guru masih menggunakan metode konvensional (ceramah) dalam menyampaikan materi pelajaran. Kurang variasi dalam menerapkan metode pembelajaran, minimnya penerapan media, juga perhatian yang kurang terhadap siswa selama proses pembelajaran.

Penggunaan metode yang kurang tepat dalam kegiatan pembelajaran, berakibat pada peran 
serta siswayang pasif. Selama ini pembelajaran hanya berpusat pada guru dan tidak berbasis masalah, sehingga siswa kurang terlatih dalam memecahkan masalah. Sebaiknya dalam kegiatan pembelajaran siswa diberikan masalah-masalah sosial yang harus dipecahkan sehingga siswa kelak terbiasa dalam menghadapi masalah-masalah sosial.

Problem Solving adalah sebuah metode pembelajaran yang menekankan pemecahan masalah dan sangat baik bagi pembinaan sikap ilmiah pada para siswa.Zain (2006: 103) mengatakan bahwa, "Problem Solving (pemecahan masalah) bukan hanya sekedar metode mengajar tetapi juga merupakan suatu metode berfikir, sebab dalam Problem Solving dapat menggunakan metode lain yang dimulai dari mencari data sampai kepada menarik kesimpulan".

Berdasarkan hasil observasi kemampuan pemecahan masalah siswa di SDN 5 Ciseureuh Purwakarta dalam pendidikan IPS dirasakan masih rendah, karena siswa diajarkan oleh guru hanya bersifat informasi dengan metode ceramah,sehingga kurang melatih kemampuan siswa dalam pemecahan masalah. Problem Solving diasumsikan mampu memberikan solusi, karena dalam Problem Solving siswa dituntut untuk mampu memecahkan sebuah masalah yang terjadi dalam kehidupan sehari-hari.

\section{B. Kajian Teori}

\section{Pengertian Problem Solving}

Problem Solving atau pemecahan masalah bukan hanya sekedar metode mengajar, tapi juga merupakan suatu metode berpikir, sebab dalam metode Problem Solving dapat menggunakan metode-metode lainnya yang dimulai dengan mencari data sampai kepada penarikan kesimpulan.
Metode Problem Solving bertujuan melatih siswa menghadapi berbagai masalah, baik masalah perorangan maupun kelompokuntuk dipecahkan secara perorangan maupun secara bersama-sama.

$$
\text { Gulo (2002: 111) }
$$

menyatakan bahwa, "Problem Solving adalah metode yang mengajarkan penyelesaian masalah dengan memberikan penekanan pada terselesaikannya suatu masalah secara menalar".

$$
\text { Sanjaya }
$$

(2009:212)

menyatakan bahwa, "Metode Problem Solving adalah metode yang mendorong anak untuk berfikir secara sistematis dengan menghadapkannya kepada problemproblemnya. metode ini juga memusatkan kegiatan pada murid. Jadi berbeda dengan metode ceramah yang mengutamakan peranan Guru".

Dalam Problem Solving kita dapat pula menggunakan metode lainnya yang dapat menunjang proses pembelajaran. Untuk mencapai hasil yang maksimal dalam pembelajaran diperlukan sebuah metode yang menunjang proses pembelajaran tersebut. Dalam Problem Solving siswa diajak untuk berpikir bagaimana memecahkan sebuah permasalahan yang ada, sehingga didapat jalan keluar untuk pemecahan masalah yang ada tersebut. Problem Solving merangsang siswa untuk berpikir mencari jalan keluar pemecahan masalah terhadap permasalahan yang ada atau yang sedang dihadapi.

Pada pembelajaran berbasis masalah peserta didik dituntut untuk melakukan pemecahan masalah yang disajikan dengan cara menggali informasi sebanyakbanyaknya, kemudian dianalisis dan dicari solusi dari permasalahan yang ada. Solusi dari permasalahan tersebut tidak mutlak mempunyai satu jawaban yang benar artinya 
siswa dituntut pula untuk belajar secara kritis. Peserta didik diharapkan menjadi individu yang berwawasan luas serta mampu melihat hubungan pembelajaran dengan aspek-aspek yang ada di lingkungannya.

Metode Problem Solving ini menekankan pada penemuan dan pemecahan masalah secara berkelanjutan. Kelebihan metode ini mendorong siswa untuk berpikir secara ilmiah, praktis, intuitif dan bekerja atas dasar inisiatif sendiri, menumbuhkan sikap objektif, jujur dan terbuka. Sedangkan kelemahannya memerlukan waktu yang cukup lama, tidak semua materi pelajaran mengandung masalah memerlukan perencanaan yang teratur dan matang, dan tidak efektif jika terdapat beberapa siswa yang pasif.

\section{Langkah-langkah}

Pembelajaran Problem Solving

Metode problem solving memiliki langkah-langkah umum, seperti yang dikemukakan oleh Mulyasa (2006:111), yakni: 1) merasakan adanya masalahmasalah yang potensial, 2) merumuskan masalah, 3) mencari jalan keluar, 4) memilih jalan keluar yang paling tepat, 5) melaksanakan pemecahan masalah, 6) menilai apakah pemecahan masalah yang dilakukan sudah tepat atau belum.

$$
\text { Depdikbud }
$$

menjelaskan bahwa, Dalam garis besarnya langkah-langkah metode Problem Solving (pemecahan masalah) dapat disarikan sebagai berikut: 1) adanya masalah yang dianggap penting, 2) merumuskan masalah, 3) analisa hipotesa, 4) mengumpulkan data, 5) analisa data, 6) mengambil kesimpulan, dan 7) menilai kembali seluruh proses masalah.

Hidayati, dkk. (2008: 26) berpendapat ada dua pendekatan dalam pemecahan masalah yaitu: 1) Menciptakan lingkungan yang merangsang sehingga siswa memperoleh motivasi yang kuat untuk menjawab permasalahan kemudian menemukan jawaban yang memadai dengan bimbingan guru yang kompeten. 2) Menghadapkan siswa kepada masalah-masalah untuk kemudian mencari pemecahannya.

\section{IImu Pengetahuan Sosial}

\subsection{Pengertian IPS}

IImu Pengetahuan Sosial yang disingkat IPS.Istilah IImu Pengetahuan Sosial dalam dunia pendidikan dasar dan menengah di negara kita muncul bersamaan dengan Kurikulum SD, SMP, SMA tahun 1975.

IPS secara program dalam dunia pendidikan relatif masih baru, walaupun dilihat dari bahannya IPSsebetulnya bukanlah hal yang baru. IPS merupakan program pendidikan pada tingkat Pendidikan Dasar dan Menengah.

IPS lahir dari keinginan para pakar pendidikan untuk membekali para siswa, agar mereka mampu menghadapi dan menangani kompleksitas kehidupan di masyarakat yang sering berkembang secara tidak terduga. Perkembangan seperti itu dapat membawa berbagai dampak yang luas.

Melalui pengajaran IPS siswa dapat memperoleh pengetahuan, keterampilan, sikap dan kepekaan untuk menghadapi hidup dengan tantangan-tantangannya.

Selanjutnya kelak mereka diharapkan mampu bertindak secara rasional dalam memecahkan masalah-masalah sosial yang dihadapi.

Somantri (Sapriya, 2012:11) menyatakan bahwa, "pendidikan IPS adalah penyederhanaan dari disiplindisiplin ilmu sosial dan humaniora, serta kegiatan dasar manusia yang diorganisasikan dan disajikan secara ilmiah dan pedagogis/psikologis untuk tujuan pendidikan'. Istilah 
pendidikan IPS atau PIPS merupakan istilah yang sejajar dengan istilah pendidikan IPA.

IPS untuk tingkat sekolah dasar erat kaitannya dengan disiplin ilmu-ilmu sosial yang terintegrasi dengan humaniora dan ilmu pengetahuan alam yang dikemas secara ilmiah dan pedagogis untuk kepentingan pembelajaran di sekolah. IPS di tingkat sekolah pada dasarnya bertujuan untuk mempersiapkan para peserta didik sebagai warga negara yang menguasai pengetahuan, sikap, dan nilai yang dapat digunakan sebagai kemampuan untuk memecahkan masalah pribadi, atau masalah sosial. Memberikan kemampuan mengambil keputusan dan berpartisipasi dalam berbagai kegiatan kemasyarakatan agar menjadi warga negara yang baik.

\subsection{Tujuan IPS}

Secara umum tujuan IPS adalah untuk mengembangkan potensi peserta didik agar peka terhadap masalah social yang terjadi di masyarakat, memiliki sikap mental positif terhadap perbaikan segala ketimpangan yang terjadi, dan terampil mengatasi setiap masalah yang terjadi sehari-hari, baik yang menimpa dirimya sendiri mau pun yang menimpa masyarakat.

Awan Mutakin, (Trianto, 2012:176) merinci sebagai berikut: 1) Memiliki kesadaran dan kepedulian terhadap masyarakat atau lingkungannya, melalui pemahaman terhadap nilai-nilai sejarah dan kebudayaan masyarakat, 2) Mengetahui dan memahami konsep dasar dan mampu menggunakan metode yang diadaptasi dari ilmu-ilmu social yang kemudian dapat digunakan untuk memecahkan masalah-masalah social, 3) Mampu menggunakan model-model dan proses berpikir serta membuat keputusan untuk menyelesaikan isu dan masalah yang berkembang di masyarakat, 4)
Menaruh perhatian terhadap isu-isu dan masalah-masalah social, serta mampu membuat analisis yang kritis, selanjutnya mampu mengambil tindakan yang tepat, 5) Mampu mengembangkan berbagai potensi sehingga mampu membangun diri sendiri agar survive yang kemudian bertanggung jawab membangun masyarakat, 6) Memotivasi seseorang untuk brtolak berdasarkan moral, 7) Fasilitator di dalam suatu lingkungan yang terbuka dan tidak bersifat menghakimi, 8) Mempersiapkan siswa menjadi warga negara yang baik dalam kehidupannya dan mengembangkan kemampuan siswa menggunakan penalaran dalam mengambil keputusan pada setiap persoalan yang dihadapinya, 9) Menekankan perasaan, emosi, dan derajat penerimaan atau penolakan siswa terhadap materi Pembelajaran IPS yang diberikan.

\section{Pemecahan Masalah Sosial \\ 4.1 Pengertian Masalah Sosial Pada hakikatnya} pembelajaran bertujuan tidak hanya memahami dan menguasai apa dan bagaimana sesuatu itu terjadi, tetapi memberikan pemahaman dan penguasaan tentang mengapa hal itu terjadi. Pemecahan masalah dalam pembelajaran IPS menjadi sangat penting, karena pada dasarnya tujuan akhir pembelajaran adalah menghasilkan siswa yang memiliki pengetahuan dan keterampilan dalam memecahkan masalah yang dihadapi kelak dalam masyarakat. Untuk menghasilkan siswa yang memiliki kompetensi yang handal dalam pemecahan masalah, maka diperlukan serangkaian strategi pemecahan masalah. Idealnya setiap masalah dapat dipecahkan dengan proses penyelesaian yang benar, tepat dan baik sesuai dengan dukungan bukti yang tersedia. Berdasarkan kajian beberapa literature terdapat banyak 
strategi pemecahan masalah yang kiranya dapat diterapkan dalam pembelajaran.

Gagne (Wena, 2011:52) menyatakan bahwa:Pemecahan masalah dipandang sebagai suatu proses untuk menemukan kombinasi dari sejumlah aturan yang dapat diterapkan dalam upaya mengatasi situasi yang baru. Pemecahan masalah tidak hanya sebagai bentuk kemampuan menerapkan aturan-aturan yang telah dikuasai melalui kegiatan-kegiatan belajar terdahulu, melainkan lebih dari itu, merupakan proses untuk mendapatkan seperangkat aturan pada tingkat yang lebih tinggi. Apabila seseorang terlah mendapatkan suatu kombinasi perasngkat aturan yang terbukti dapat dioperasikan sesuai dengan situasi yang sedang dihadapi, maka ia tidak saja dapat memecahkan suatu masalah. Tapi juga dapat menemukan sesuatu yang baru. Sesuatu yang dimaksud adalah perangkat prosedur atau strategi yang memungkinkan seseorangdapat meningkatkan kemandirian dalam berpikir. Idealnya aktivitas belajar siswa tidak hanya difokuskan pada upaya mendapatkan pengetahuan sebanyak-banyaknya, melainkan bagaimana menggunakan segenap pengetahuan yang didapat guna menghadapi situasi baru atau memecahkan masalah khusus yang ada kaitannya dengan bidang studi yang dipelajari. Hakikatnya pemecahan masalah adalah melakukan operasi prosedural urutan tindakan, tahap demi tahap secara sistematis, dalam memecahkan suatu masalah.

Raka Joni (Wena, 2011:52) bahwa proses yang dimaksud bukan dilihat sebagai perolehan informasi yang terjadi sevara satu arah dari luar ke dalam diri siswa, melainkan sebagai pemberian makna oleh siswa kepada pengalamannya melalui proses asimilasi dan akomodasi yang bermuara pada pemutakhiran proses kognitifnya'. Kemampuan pemecahan masalah sangat penting artinya bagi siswa dan masa depannya kelak. Para ahli pembelajaran sependapat bahwa kemampuan pemecahan masalah dalam batas-batas tertentu, dapat dibentuk melalui bidang studi atau disiplin ilmu yang diajarkan (Suharsono, dalam Wena 2011:53). Penyelesaian masalah adalah proses pemikiran dan mencari jalan keluar dari masalah tersebut.

Dalam pembelajaran IPS sumber belajar bisa diambil dari halhal yang bersifat aktualyang terjadi dalam masyarakat.

Menurut Gulo (Thobroni, 2012:335) menyatakan pemilihan materi seperti itu memerlukan beberapa criteria sebagai berikut: 1) Bahan pelajaran bersifat conflict issue atau controversial. Bahan seperti ini dapat direkam dari peristiwa-peristiwa kongkret dalam bentuk audio visual atau kliping atau disusun oleh guru, 2) Bahan yang dipilih bersifat umum atau tidak terlalu asing bagi siswa, 3) Bahan tersebut mendukung pengajaran dan pokok bahasan dalam kurikulum sekolah, 4) Bahan tersebut mencakup kepentingan orang banyak dalam masyarakat, 5) Bahan tersebut merangsang perkembangan kelas mengarah pada tujuan yang dikehendaki, 6) Bahan tersebut menjamin kesinambungan pengalaman siswa.

\subsection{Langkah-langkah \\ Pemecahan Masalah}

Dalam pemecahan masalah dibutuhkan langkah-langkah atau tahapan-tahapan agar proses pemecahan masalah tersebut dapat berjalan dengan lancar, dan menghasilkan penyelesaian atau pemecahan yang diharapkan. Menurut J. Dewey (Thobroni, 2012:336) menyatakan bahwa pemecahan masalah ini dapat 
dilakukan dengan enam tahap, sebagai berikut: merumuskan masalah, menelaah masalah, merumuskan hipotesis, mengumpulkan dan mengelompokkan data sebagai bahan pembuktian hipotesis, pembuktian hipotesis, dan membuat kesimpulan.

\section{Metode Penelitian \\ 1. Jenis Penelitian}

Jenis penelitian ini menggunakan Penelitian Tindakan Kelas (PTK). Penelitian ini difokuskan pada situasi kelas, dalam penelitian tindakan kelas ini, guru dapat berdiri sendiri terhadap praktek-praktek pembelajaran yang dilakukan di kelas melalui tindakantindakan yang direncanakan, dilaksanakan, dan dievaluasi. Hal ini sesuai dengan karakteristik penelitian tindakan kelas yaitu adanya tindakan-tindakan aksi tertentu unyuk memperbaiki proses belajar mengajar di kelas.

Menurut Ebbut (Kasbolah, 1999:13), penelitian tindakan kelas adalah studi yang sistematis yang dilakukan dalam upaya memperbaiki praktek-praktek dalam pendidikan dengan melakukan tindakan praktis serta refleksi, penelitian sebagai suatu rangkaian siklus yang berkelanjutan di dalam dan antara siklus-siklus."

Tujuan akhir penelitian tindakan kelas adalah untuk: 1) meningkatkan kualitas praktek pembelajaran di sekolah, 2) meningkatkan relevansi pendidikan, 3) meningkatkan mutu hasil pendidikan, dan 4) meningkatkan efisiensi pengolahan pendidikan.

\section{Lokasi dan Subjek Penelitian}

Penelitian diadakan di Kelas

V SDN Ciseureuh V

Kecamatan/Kabupaten Purwakarta. Subjek penelitiannya berjumlah 37 orang siswa, yang terdiri dari 22 perempuan dan 15 orang laki-laki serta 1 orang guru.

\section{Instrumen Penelitian}

Instrumen penelitian yang dipergunakan dalam mengumpulkan data untuk penelitian ini adalah sebagai berikut:

1. Pedoman Observasi, digunakan untuk mengumpulkan data yang berkaitan dengan aktivitas siswa dalam pembelajaran.

2. Tes hasil belajar, digunakan untuk mengetahui kemampuan siswa yang berkaitan dengan penguasaan terhadap bahan ajar.

\section{Analisis Data}

Data kuantitatif adalah data yang berbentuk angka atau bilangan. Sesuai dengan bentuknya, data kuantitatif dapat diolah atau dianalisis menggunakan teknik perhitungan matematika atau statistika. Penyajian data dalam bentuk tabel, yaitu penyajian data yang disusun berupa baris dan kolom yang berisikan kumpulan angka-angka berdasarkan kategori tertentu. Bentuk tabel yang digunakan dalam penelitian ini adalah tabel frekuensi.

untuk Data kuantitatif $\begin{array}{r}\text { digunakan } \\ \text { mengetahui tingkat }\end{array}$ pemahaman peserta didik dalam menguasai materi pembelajaran melalui tes. Untuk mengetahui tingkat pemahaman peserta didik digunakan indikator nilai rata-rata, daya serap peserta didik (DSS) dan daya serap klasikal (DSK). Rumus untuk menentuka nilai rata-rata peserta didik menurut Hermawan (2007:32):

$\mathrm{X}=\frac{\sum f x}{\Sigma f}$

Keterangan:

$X=$ Rata-rata nilai

$X=$ Jumlah nilai

$\mathrm{F}=$ Jumlah peserta didik

DSS $\frac{\text { Jumlah Skor Total Subyek }}{\text { Jumlah Skor Total Maksimal }} 100 \%$

Peserta didik dikatakan tuntas

belajarnya apabila DSS $\geq 65 \%$ 
DSK=

$\frac{\text { Jumlah Siswa yang Memperoleh nilai }}{} \times$

$100 \%$

Kelas dikatakan tuntas jiak DSK $\geq$ $85 \%$

Untuk data kualitatif, yakni data yang dihasilkan dari hasil observasi digunakan skala penilaian dari $A$ sampai $D$, dengan interpretasi $A=$ Baik sekali, $B=B a i k, C=$ cukup, $\mathrm{D}=$ Kurang.

Selanjutnya setiap siklus diamati dan dilaporkan secara kualitatif. Setiap siklus diambil ratarata presentasinya kemudian dikonversikan dalam aturan : Hermawan (2007:32).

$\geq 85 \% \quad=$ Baik sekali $75 \%-84 \%$ $=$ Baik 65\%-74\% = Sedang $\leq 64 \%=$ Kurang

\section{Pembahasan}

Dalam penelitian ini pelaksanaan siklus tindakan dibatasi sampai siklus kedua. $\mathrm{Hal}$ ini didasarkan atas perolehan belajar siswa yang sudah baik. Hasil rangkaian pelaksanaan tindakan kesatu sampai tindakan kedua menunjukan bahwa penerapan metode problem solving pada proses pembelajaran IPS dapat meningkatkan kemampuan pemecahan masalah siswa dan hasil belajarnya.

Berdasarkan hasil observasi selama 2 siklus, menunjukkan terdapat peningkatan mengenai kemampuan pemecahanmasalah siswa pada aspek menjawab masalah, mengumpulkan bahan untuk menjawab masalah, kemampuan menyampaikan hasil penyelidikan, dan membuat kesimpulan. Hal tersebut dapat dilihat pada diagram di bawah ini:

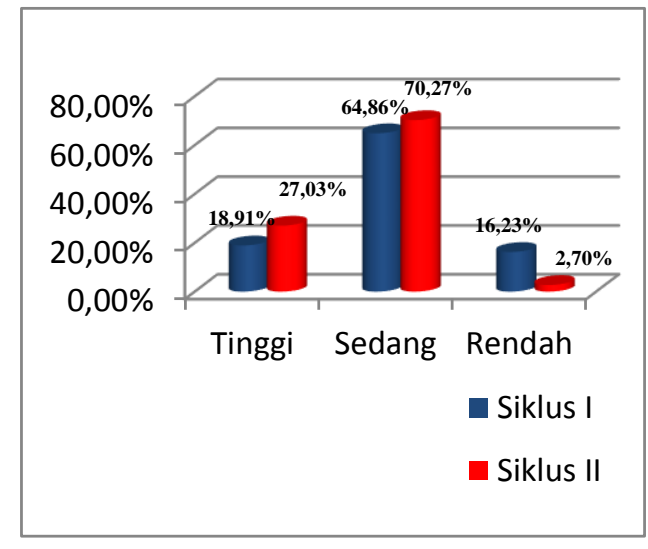

\section{Gambar 1. Diagram Peningkatan Kemampuan \\ Pemecahan Masalah}

$\begin{array}{rrr}\text { Berdasarkan } & \text { gambar } \\ \text { diagram batang } & \begin{array}{r}\text { atas, } \\ \text { menunjukkan }\end{array} \text { bahwaterdapat }\end{array}$ perbedaan hasil observasi siklus pertama sampai siklus kedua. Hal tersebut dapat dilihat dari siklus pertama masih banyak siswa yang berada pada kategori kurang, dan hanya sedikit siswa yang berada pada kategori tinggi, berbeda dengan sikluskedua, ada 1 orang siswa yang berada pada kategori rendah, dan mayoritas siswa berada pada kategori tinggi.

Tabel 1. Hasil Belajar IPS Siswa

\begin{tabular}{|c|c|c|c|c|}
\hline \multirow{2}{*}{$\begin{array}{c}\text { Siklu } \\
\text { s }\end{array}$} & $\begin{array}{c}\text { Banya } \\
k\end{array}$ & \multicolumn{3}{|c|}{ Hasil Belajar } \\
\cline { 3 - 5 } & Siswa & Jlh & $\begin{array}{c}\text { Rata } \\
- \\
\text { Rata }\end{array}$ & $\begin{array}{c}\text { Prosenta } \\
\text { se }\end{array}$ \\
\hline $\begin{array}{c}\text { Pr } \\
\text { a }\end{array}$ & 37 & $\begin{array}{c}214 \\
0\end{array}$ & $\begin{array}{c}55,9 \\
5\end{array}$ & $46 \%$ \\
\hline 1 & 37 & $\begin{array}{c}269 \\
0\end{array}$ & $\begin{array}{c}72,7 \\
0\end{array}$ & $78,37 \%$ \\
\hline 2 & 37 & $\begin{array}{c}294 \\
0\end{array}$ & $\begin{array}{c}79,4 \\
6\end{array}$ & $91,89 \%$ \\
\hline
\end{tabular}

Data di atas, menunjukkan bahwa hasil belajar IPS dengan menggunakan penerapan metode problem solving menunjukkan peningkatan yang signifikan. Hal ini 
dapat dilihat perkembangan dari mulai pra siklus yakni sebelum menerapkan metode problem solving, siswa hanya memperoleh prosentase sebesar $46 \%$ dan jumlah siswa yang mendapatkan nilai di atas KKM yaitu17 orang (46\%), pada siklus pertama setelah menggunakan penerapan metode problem solving mengalami peningkatan perolehan hasil belajar siswa sebesar $78,37 \%$ yakni 29 siswa yang memperoleh nilai diatas $\mathrm{KKM}$, dan pada siklus kedua peningkatan cukup memuaskan dengan perolehan prosentase sebesar $91,89 \%$, atau 34 orang siswa dari jumlah siswa sebanyak 37 orang.

\section{E. Kesimpulan}

Berdasarkan hasil penelitian selama dua siklus dapat disimpulkan sebagai berikut:

Pertama. Dilihat dari aspek prosesnya menunjukkan bahwa, kemampuan pemecahan masalah siswa kelas V SDN Ciseureuh pada aspek kemampuan menjawab pertanyaan, aktivitas dalam mengumpulkan data, mengemukakan hasil penyelidikan, dan membuat kesimpulan dalam pembelajaran IPS dengan menerapan metode Problem Solving, menunjukkan peningkatan yang signifikan.

Kedua. Dilihat dari aspek hasil belajar, menunjukkan peningkatan rata-ratanya naik sebesar 23,51, ssedangkan dilihat dari ketuntasan belajarnya naik sebesar 45,89\%. belajar siswa.

\section{Daftar Rujukan}

Depdikbud. (1997). Pokok-pokok Pengajaran Biologi dan Kurikulum 1994. Jakarta: Depdikbud.

Hidayati,dkk.(2008). Pengembangan Pendidikan IPS SD. Jakarta: Dikti, Depdiknas.
Gulo, W. (2002). Strategi Belajar Mengajar. Jakarta : PT. Grasindo.

Hermawan, R. dkk. (2007) Metode Penelitian Pendidikan Sekolah

Dasar. Bandung: UPI Press.

Kasbolah. (1998/1999). Penelitian Tindakan Kelas. Malang : Depdikbud

Sanjaya, Wina (2009). Strategi Pembelajaran Berorientasi Standart Proses Pendidikan Jakarta: Kencana Prenada

Sapriya, H. (2007). Pembelajaran dan Evaluasi Hasil Belajar IPS. Bandung : UPI PRESS

(2009). Pendidikan IPS Konsep dan Pembelajaran. Bandung: PT. Rosdakarya.

Thobroni, M. (2012). Belajar dan Pembelajaran. Teori dan Praktik. Yogyakarta: Ar-Ruzz Media.

Trianto. (2011). Panduan Lengkap Penelitian Tindakan Kelas Teori dan Praktik. Jakarta : Prestasi Pustaka Publisher (2012). Mendesain Model Pembelajaran InovatifProgresif. Jakarta: Kencana.

Wena, Made. (2008). Strategi Pembelajaran Inovatif Kontemporer. Malang: Bumi Aksara.

Zain, A. dan Bahri, S. Djamarah. (2006). Strategi belajar mengajar. Jakarta: Rineka Cipta.

\section{Riwayat Penulis}

Kanda Ruskandi adalah dosen UPI kampus Purwakarta pengampu mata kuliah yang berkaiatan dengan IImu Pengetahuan Sosial pada Program Studi Pendidikan Guru SD. Alamat yang dapat dihubungi UPI Kampus Purwakarta Jl. Veteran No.8. 